\title{
Proces deinstitucionalizacije klinika za psihijatriju u Hrvatskoj
}

\author{
Maja Odorjan*, Ivan Balabanić**, Tina Štefan***
}

\begin{abstract}
Sažetak
U radu se proučava proces deinstitucionalizacije klinika za psihijatriju u Hrvatskoj, odnosno njegovi početci, oblici i pokazatelji. Glavni je cilj istraživanja definirati obrasce procesa deinstitucionalizacije „totalnih institucija“ na primjeru klinika za psihijatriju u Hrvatskoj. Specificirani ciljevi istraživanja odnose se na glavne razloge $i$ indikatore procesa, mišljenja stručnjaka i zaposlenika nevladinih organizacija (NVO). Korištena je metoda intervjua s ukupno 11 sudionika. Na temelju provedenog istraživanja zaključuje se da proces deinstitucionalizacije u Hrvatskoj postoji u kontekstu klinika za psihijatriju te da je, između ostalog, ovisan o državnim sredstvima. Proces se odvija u obliku dnevnih bolnica, potpore i raznih terapija koje uključuju korisnike klinika za psihijatriju u zajednicu. Uspješnost procesa, kao i njegov daljnji razvoj, uvjetovani su uključenjem i suradnjom institucija za zapošljavanje, obrazovanje te čitave bliže i daljnje zajednice.

Ključne riječi: institucije, „totalne institucije“, proces deinstitucionalizacije, klinike za psihijatriju
\end{abstract}

\section{Uvod}

Deinstitucionalizacija se kao proces može primijeniti na razne institucije, od institucija kao što su, primjerice, rodbinske, političke, kulturne, stratifikacijske i ekonomske institucije (Bruce i Yearley, 2006, 283) pa do „totalnih institucija“ kao što su klinike za psihijatriju (Goffman, 2011) i zatvori (Foucault, 1994). Taj termin ima nekoliko značenja, a Oxford Dictionary (2018) definira ga kao otpuštanje korisnika iz ustanove, kao što je klinika za psihijatriju ili zatvor, u kojoj je dugo boravio (Pow, 2012, 1). Nadalje, prema Shenu i Snowdenu (2014), deinstitucionalizacija je politika koja zahtijeva pomak u praksi skrbi za duševne bolesni-

* Maja Odorjan, mag. soc., MSA Adria d.o.o. Adresa: Petrinjska 42a, 10000 Zagreb, Hrvatska. Epošta:maja.odorjan@gmail.com

** Doc. dr. sc. Ivan Balabanić, Hrvatsko katoličko sveučilište. Adresa: Ilica 242, 10000 Zagreb, Hrvatska. E-pošta: ivan.balabanic@unicath.hr

*** Tina Štefan, mag. soc., Društvo osoba s tjelesnim invaliditetom Međimurske županije. Adresa: Dr. Ante Starčevića 1, 40000 Čakovec, Hrvatska. E-pošta: tina.stefan05@gmail.com 
ke od institucionalnih sredina ka zajednici. Proces deinstitucionalizacije u zapadnim je zemljama započeo otprilike šezdesetih i sedamdesetih godina 20. stoljeća te je u konstantnom razvoju (Jakovljević i Begić, 2013, 19). Razmjeri procesa deinstitucionalizacije ovise o nizu različitih čimbenika, kao što su mogućnosti pojedine zemlje, što znači da to ovisi o upravljanju, politici te zemlje, financijama, ustroju i zakonima te, naravno, o samim korisnicima i zaposlenicima određenih institucija. Prema tome se razvijaju daljnje usluge koje omogućavaju inkluziju korisnika u zajednicu te im pružaju podršku i koordinaciju (Open Society Foundations, 2015). Također, kao što to pokazuju razni primjeri, institucije mogu poprimiti oblik pružatelja usluga ili se, s druge strane, mogu potpuno smanjiti ili zatvoriti, a osoblje i korisnici mogu se premjestiti u druge oblike smještaja izvan klinika. Kako bi došlo do promicanja mentalnog zdravlja općenito, potrebna je suradnja psihijatrije s drugim strukama, poput javnog zdravstva, psihologije, socijalnog rada itd. (Štrkalj Ivezić i dr., 2010, 39). U Hrvatskoj je također došlo do razvoja raznih službi, programa podrške i pokušaja inkluzije u zajednicu (Rozman, 2007). U kontekstu klinika za psihijatriju, deinstitucionalizacija se odnosi na njihovo zatvaranje ili na smanjenje njihova kapaciteta te osnivanje dnevnih bolnica, smještanje u stanove, udomljavanje korisnika institucija te provođenje raznih radnih terapija u zajednici (Jakovljević i Begić, 2013).

\section{Totalne institucije i deinstitucionalizacija}

\subsection{Totalne institucije}

Termin „totalne institucije“ prvi je detaljno razradio Erving Goffman u svojem djelu Azili: Eseji o društvenom položaju pacijenata bolnica za mentalno oboljele i drugih utočenika, prvi put publiciranom 1961. godine. Goffman u svojem djelu navodi vrste totalnih institucija, njihove karakteristike i obilježja te odnos osoblja i „utočenika“, tj. osoba koje borave u njima. Do saznanja o postojanju institucija koje imaju karakter totalne institucije došao je tako što je tijekom 1955. i 1956. godine provodio terensko istraživanje u klinikama za psihijatriju. Proučavao je ponašanje i društveni svijet bolničkih „utočenika“ te njihov subjektivni doživljaj tog svijeta. »Totalna institucija može se definirati kao mjesto boravka i rada gdje više pojedinaca sličnog položaja, odsječenih od šireg društva tijekom jednog zajedničkog vremenskog perioda, vodi jedan zatvoren, kontroliran život « (Goffman, 2011, 13). Goffman navodi kako su društvene ustanove, tj. institucije, mjesta poput soba, nizova prostorija, građevina ili postrojenja. U takvim prostorijama odvijaju se aktivnosti jedne specifične vrste. Nadalje, objašnjava kako totalne institucije, između ostalog, karakterizira »barijera prema društvenim odnosima s vanjskim i barijera koja ne dozvoljava napuštanje i koja je često ugrađena u određeno fizičko postrojenje, u obliku zaključanih kapija, visokih zidova, bodljikave žice, stijena, vode, šume ili pustare « (Goffman, 2011, 18).

Totalne institucije dijeli na pet grupa. To su: domovi za nemoćne (slijepi, stari, siročad, siromašni itd.), institucije koje brinu o osobama koje se ne mogu 
brinuti za sebe (osobe sa zaraznim bolestima), institucije osnovane radi zaštite društva od opasnih osoba (zatvori, kaznionice, logori za ratne zarobljenike i koncentracijski logori), institucije za obavljanje određenih poslova (npr. vojarne, brodovi, internati, radni kampovi itd.) i „religiozne“ institucije poput samostana.

Kada opisuje karakteristike totalnih institucija, naglašava da one probijaju granice koje razdvajaju sfere života, u smislu da se u totalnim institucijama sve odvija na jednom mjestu, za razliku od „vanjskog“ svijeta, gdje ljudi uglavnom sve svoje aktivnosti obavljaju na drugim mjestima (spavanje, rad itd.). Također, aktivnosti u totalnim institucijama izvode se u društvu svih drugih članova te su tijekom dana raspoređene neposredno jedna iza druge (Goffman, 2011). Nadalje, »u totalnim institucijama postoji osnovna podjela između velike grupe kojom se upravlja, a koja se prikladno može nazvati utočenicima, i manje grupe koja ih nadgleda. Utočenici obično žive u instituciji i imaju ograničen kontakt sa svijetom izvan zidina« (Goffman, 2011, 20-21).

\subsection{Proces deinstitucionalizacije}

Berger i Luckmann (1992) smatraju da se zbog raznih povijesnih razloga, kao što je industrijalizacija, doseg institucionaliziranih djelatnosti može smanjiti. Taj makrofenomen može se vidjeti na primjeru obrazovanja (učenje putem Interneta), braka i obitelji (slobodniji oblici braka i obitelji koji se lakše raskidaju, primjerice kohabitacija) ili na primjeru totalnih institucija poput klinika za psihijatriju.

Kada govorimo o klinikama za psihijatriju, proces deinstitucionalizacije možemo definirati kao »dugoročan trend $\mathrm{u}$ kojem se manje pacijenata nalazi u klinikama za psihijatriju te je manje liječenja u javnim bolnicama «(Encyclopedia of Mental Disorders, 2017).

Trend se odnosi na proces zatvaranja javnih bolnica te premještanje pacijenata u zajednicu uz pomoć raznih zdravstvenih usluga, a pojavio se u kasnom 20. stoljeću (Encyclopedia of Mental Disorders, 2017). Naime, uspješno osigurana podrška zajednice jedan je od mogućih putova koji vode ostvarivanju načela deinstitucionalizacije (Grozdanić i Rittossa, 2017, 976).

Primarni razlozi deinstitucionalizacije su: humanost, koje je nedostajalo u prijašnjim načinima liječenja, materijalni razlozi te uspješniji načini terapije kojima se pacijente premješta u zajednicu, gdje se oni ponovno uključuju u zajednicu te na taj način postaju aktivni i korisni članovi društva (Open Society Foundations, 2017). Osim humanosti, koja je jedan od središnjih pojmova procesa, potrebno je staviti naglasak i na financijske razloge. Oni, naime, proizlaze iz ekonomije te se oblikuju u skladu s njom, što je razlog da se o deinstitucionalizaciji može govoriti kroz prizmu neoliberalne ekonomije (Miljenović, 2013, 60). Gledano na taj način, proces deinstitucionalizacije promatra se kao prilagodba na rad s manjim sredstvima, a do smanjenja sredstava dolazi ako država manje ulaže u zdravstvo i ostale sektore.

Goffman napominje kako je najteži dio, nakon boravka u totalnoj instituciji, povratak u vanjski svijet. »U kasnijoj fazi životnog ciklusa, nastojanje da se nado- 
knadi vrijeme koje nije provedeno u obrazovnom ili poslovnom napredovanju, u zabavi, u podizanju djece — može se pokazati nemogućim«(Goffman, 2011, 28).

Pitanje izlaska iz totalne institucije ovisi o ponašanju „utočenika“. Izlazak iz totalne institucije opisuje se kao proces u kojem „utočenik“ s jedne strane odbrojava dane do izlaska, a s druge je strane zabrinut zbog toga kako će biti prihvaćen u vanjskom svijetu i hoće li uspjeti. Neki zbog toga namjerno prilikom izlaska naprave pogrešku kako bi se vratili u totalnu instituciju i izbjegli problem suočavanja s vanjskim svijetom. Proaktivnim statusom autor opisuje stav koji zauzima prilikom ulaska u instituciju — »ne samo da se njegova društvena pozicija unutar zidova radikalno razlikuje od onoga što je bilo vani, već, kako sam saznaje, ako i kada izađe van, njegova društvena pozicija izvan institucije nikad više neće biti onakva kakva je bila prije ulaska u instituciju « (Goffman, 2011, 74). Goffman u tom kontekstu spominje „stigmatizaciju“. U svojem djelu Stigma govori kako se u prošlosti taj termin odnosio na fizički oštećene ljude, a danas se više ne odnosi toliko na fizičke pokazatelje, nego na osramoćenost. Dakle, u ovom smislu osramoćenost zbog boravka u nekoj od totalnih institucija. Goffman to opisuje na način da pojedinac koji izlazi iz klinike za psihijatriju nailazi na hladan doček u vanjskom svijetu. To se može primijetiti primjerice kod prijava za posao i slično. »Dalje, otpust dolazi vjerojatno baš onda kada se utočenik konačno nauči snalaziti unutar institucije i kada zadobije privilegije za koje je na bolan način saznao da su bitne (Goffman, 2011, 75).

Za „utočenika“ je to, prema Goffmanu, pomicanje s vrha malog svijeta na dno velikog svijeta. No kada se osoba i vrati u vanjski svijet, i dalje postoji mogućnost da joj je sloboda na neki način ograničena.

\section{Metodologija istraživanja}

\subsection{Ciljevi istraživanja}

Glavni je cilj istraživanja definirati obrasce procesa deinstitucionalizacije totalnih institucija na primjeru klinika za psihijatriju u Hrvatskoj. Iz glavnog cilja istraživanja proizlaze specificirani ciljevi istraživanja, a to su: odrediti glavne razloge i pokazatelje procesa deinstitucionalizacije, ispitati mišljenja stručnjaka i pojedinaca iz NVO sektora o procesu deinstitucionalizacije klinika u Hrvatskoj, ustanoviti kako je započeo proces deinstitucionalizacije i kakav je njegov daljnji tijek, utvrditi koji su faktori koji utječu na proces te koji su glavni obrasci i oblici deinstitucionalizacije.

\subsection{Metoda, instrument, sudionici i provedba istraživanja}

Pri prikupljanju podataka korištena je metoda intervjua, odnosno polustrukturirani intervju u kojem istraživač ima unaprijed zadana pitanja koja želi postaviti sudioniku, ali dopušta i da sudionik samoinicijativno pokrene neku temu, dok god se ona kreće po predviđenom planu ispitivanja. Konkretno, upitnik se sastojao od 19 pitanja. Početna pitanja odnosila su se na godine iskustva rada su- 
dionika na trenutačnom radnom mjestu. Nadalje, slijedila su pitanja poput shvaćanja pojma deinstitucionalizacije, utjecaj države, politike i ekonomije na poslovanje klinika za psihijatriju, prednosti i nedostatci procesa deinstitucionalizacije, detalji vezani uz poslovanje i prostor klinike, predviđanje budućnosti klinika iz konteksta procesa deinstitucionalizacije te pitanja vezana uz djelovanje i utjecaj udruga na cjelokupan proces.

U istraživanju je sudjelovalo ukupno 11 sudionika, od kojih su četiri sudionika zaposlena u klinikama za psihijatriju, a sedam u NVO sektoru, tj. udrugama koje se bave problemima u psihijatriji. Intervjui su provedeni u razdoblju od travnja do studenog 2017. godine. Provedeni su na radnim mjestima sudionika i trajali su u prosjeku 30-ak minuta.

\section{Rezultati i rasprava}

Prema mišljenju sudionika, trenutačna situacija u hrvatskoj psihijatriji znatno je bolja nego je to bio slučaj prije 30-ak godina. Tako jedan od sudionika koji radi u klinici za psihijatriju kaže: »Puno lošija. Prije deset i dvadeset godina nije isto. Prije dvadeset godina bila je puno puno lošija. Apsolutno se išlo samo na instituciju i sve se u instituciji rješavalo i puno socijalne problematike duševnih bolesnika što danas, na sreću, više nije ni slično« (Sudionik 4).

Izjave sudionika preklapaju se u opisu klinika za psihijatriju i samog postupanja prema njihovim korisnicima. Klinike su prije nekoliko godina bile mjesta u kojima su pojedinci bili odsječeni od društva, a njihov život zatvoren i kontroliran. U novije vrijeme, situacija se promijenila, no to je i dalje „u povojima“, prema mišljenju pojedinca iz NVO sektora:

Hrvatska psihijatrija prati trendove onih razvijenih zemalja, ali je, kao i u svemu ostalom, u zaostatku barem 20-ak godina za njima. U hrvatskoj psihijatriji jako se puno toga promijenilo u posljednjih 20 -ak godina, na bolje. Sam pristup pacijentu, bolji lijekovi, obnova infrastrukture, to jest samih institucija, otvaranje dnevnih bolnica, malo pojačani interes medija za tu problematiku (Sudionik 7).

Kao jedan od važnih čimbenika otkrivanje je i dolazak novih lijekova te njihova dostupnost na tržištu. Mogućnosti liječenja psihijatrijskih bolesnika zbog toga su puno bolje, a tomu svjedoče i sudionici kada opisuju vlastite početke u psihijatriji navodeći da su postojale situacije kada su se pacijenti primjerice fizički obuzdavali na način da su stavljani u stezulju, no to se s godinama promijenilo te su načini liječenja puno humaniji i u mnogočemu drugačiji.

Znači, nekada, kada sam ja počeo raditi, izbor lijekova, takozvanih antipsihotika, bio je vrlo mali tako da se nerijetko moralo kod agitiranih bolesnika pristupiti njihovom fizičkom obuzdavanju, na primjer, stavljanje u stezulju i tako dok se ne bi smirili. Međutim, danas su na tržištu prisutni medikamenti koji to vrlo uspješno rješavaju tako da je liječenje i pristup psihijatrijskim bolesnicima danas puno humaniji nego je to bio ranije (Sudionik 3). 
S druge strane, pojedinci koji djeluju u okviru NVO sektora ne vide znatnije poboljšanje po pitanju psihijatrijskog liječenja:

Unazad trideset godina nije se promijenilo puno, jer, koliko je meni poznato, psihosocijalni rad se organizira iz psihijatrijskih bolnica, na način da se otvaraju zaštitne radionice koje su organizirane po principima medicinskog modela, gdje se pacijenti tretiraju kao pacijenti, gdje nema kreativnosti u aktivnostima, odnosno aktivnosti nisu usmjeravane korisnicima i njihovim potrebama, već su nametnute odozgo. Unatoč tomu, u sustavima ima sjajnih stručnjaka, entuzijasta, koji svojim aktivnostima i radom mijenjaju stvari na individualnoj razini (Sudionik 11).

Sudionik iz NVO sektora smatra da su značajnije promjene još uvijek uočljivije na individualnim ili mikrorazinama te da tek trebaju obuhvatiti psihijatriju u cjelini. Da taj problem na isti način vide i regulatorna tijela, očituje se kroz donošenje raznih strategija čiji je cilj pomaknuti pitanje mentalnog zdravlja iz teorije $\mathrm{u}$ praksu.

Treba spomenuti i proglas od 15 točaka za poštivanje prava osoba s duševnim smetnjama donesen 2017. godine na okruglom stolu Hrvatskog psihijatrijskog društva, pod nazivom Prava osoba s duševnim smetnjama u Hrvatskoj u kontekstu Liste prava osoba s duševnim smetnjama (Bill of rights form persons with mental illness) Svjetske psihijatrijske asocijacije (HPD, 2017). Bitan je i dokument Zakon o zaštiti osoba s duševnim smetnjama, čije točke propisuju načela, organizaciju, pretpostavke za primjenu mjera i postupanje prema osobama s duševnim smetnjama (Narodne novine, 1998). O tome govori izjava sudionika:

Pa mislim da se više posvećuje vremena i interesa području prava psihijatrijskih pacijenata, bolje se provode neke zakonske odredbe, Zakon o zaštiti prava pacijenata, ima nešto veći broj izvanbolničkih programa, liječenja, ima podružni broj programa odvijen u sustavu javnog zdravstva i tako... postoje neki razvoji i veći broj usluga u zajednici (Sudionik 1).

Iz izjava sudionika možemo zaključiti da su promjene još uvijek vidljivije na individualnim primjerima, a na makrorazini tek se implementiraju pojedine strategije. U nekim područjima odnos prema pacijentima značajno je kvalitetniji, za što su prvenstveno zaslužni novi farmaceutski proizvodi i načini liječenja. S druge strane, još uvijek nije u potpunosti zaživio mehanizam koji bi pacijente $s$ kliničkog liječenja usmjerio na puno humanije i financijski isplativije liječenje u zajednici. Postoje individualni projekti i aktivnosti pojedinih udruga civilnog društva, ali organizirani mehanizam unaprjeđenja psihijatrije u cijelosti još je uvijek u fazi strategije i tek se treba implementirati.

\subsection{Pogled struke na deinstitucionalizaciju klinika u Hrvatskoj}

Proces deinstitucionalizacije klinika u Hrvatskoj nema svoj službeni početak, nego se odvija u različitim područjima kroz periodične aktivnosti. Sam proces nema ni usklađen naziv u okviru struke te ga neki od sudionika ovog istraživanja nazivaju i case management, koji se odnosi na oblik posebne psihijatrijske prakse razvijene u zemljama gdje postoji psihijatrija u zajednici s ciljem liječenja duševnih bolesnika (Štrkalj Ivezić i dr., 2010, 28). Takvo shvaćanje procesa deinstitu- 
cionalizacije zajedničko je većini sudionika koji su sudjelovali u intervju, a kao primjer može poslužiti izjava jednog od njih:

Deinstitucionalizacija nije proces zatvaranja psihijatrijskih bolnica i domova socijalne skrbi, nego proces transformacije istih u kojem su bolnice i domovi dio koordiniranog sustava liječenja u skrbi čija je namjena da pružaju kratkotrajno liječenje s mogućnošću nastavka liječenja u izvanbolničkim programima, a da su programi stanovanja tamo gdje ljudi žive samostalno u svom stanu ili u manjim stambenim jedinicama u kojima se pruža podrška vezano za povećanje samostalnosti za život i rad i socijalno uključivanje u život zajednice (Sudionik 9).

Takvo shvaćanje procesa odgovara podjeli Bertrama Browna (1975), prema Bachrach (1976, 1), koji deinstitucionalizaciju psihijatrije dijeli na tri komponente, a to su: sprječavanje smještanja u psihijatrijske ustanove kroz mjere liječenja u zajednici, puštanje u zajednicu institucionaliziranih pacijenata koji su za takvu promjenu adekvatno pripremljeni te osnivanje i održavanje podupirućih sustava zajednice za neinstitucionalizirane osobe na način da primaju mentalnu pomoć $u$ zajednici. Nadovezujući se na spomenuto, bitno je naglasiti mogućnost boravka pojedinca u vlastitom domu, gdje se također mogu odvijati programi liječenja. Taj važan segment procesa značajno je zamijećen u izjavama sudionika. No kada govorimo o (izvanbolničkom) liječenju, potreban je oprez jer i dalje postoje i postojat će pojedinci kojima je nužno potrebno bolničko liječenje, a u tom je slučaju vrlo važna međusobna povezanost i ravnoteža sustava, izvanbolničkih i bolničkih programa.

Ono što je također bitno razjasniti, prema riječima sudionika, jest da se termin „deinstitucionalizacija“ često zamjenjuje terminom „humanizacija“.

Izgradnja manjih objekata za različite vrste korisnika znači humanizaciju, ali ne i deinstitucionalizaciju — a to često brkamo (pa i samo Ministarstvo za demografiju, mlade i socijalnu politiku). Deinstitucionalizacija znači da je osoba uspjela ostati u svom kućnom okruženju uz podršku različitih službi sa strane. Možda bi trebalo uvesti pojam kućnog tretmana ili skrbi (Sudionik 8).

Iako se izjave sudionika donekle podudaraju, i dalje postoje neke manje razlike u shvaćanju, a na kraju i primjeni samog termina deinstitucionalizacija. Tako $\mathrm{s}$ jedne strane taj naziv ide u smjeru prebacivanja korisnika u manju instituciju, a s druge se strane on odnosi isključivo na boravak osoba u vlastitom domu. $\mathrm{Na}$ kraju, to je i smisao cijelog procesa — organizacija života osoba tako da borave u poznatom okruženju, odnosno vlastitim domovima, uz podršku mobilnih timova, šire zajednice i obitelji. U izjavama sudionika glavni je naglasak na pojmovima zajednice i humanosti te dnevne bolnice.

Proces deinstitucionalizacije u Hrvatskoj se odvija, a ovisno o materijalnim sredstvima, načinu organizacije, edukaciji i drugim faktorima ovisi kako će se održati njegovi produkti i oblici, kao što su primjerice dnevne bolnice, udruge i slično, što potvrđuje i izjava sudionika:

Politika mora sudjelovati u procesu deinstitucionalizacije. Udruge nisu dovoljno moćne, one trebaju biti korektiv, dopuna, ali ako udruge vode taj proces, to djeluje neozbiljno. Proces mora voditi politika. Faktori: novac, zajednički stav svih sudioni- 
ka, odlučnost da se dosegne cilj. Kao što znamo, u Hrvatskoj se sa svakom promjenom vlasti mijenjaju ljudi i odluke (Sudionik 10).

Budući da bi u procesu trebali sudjelovati i sudjeluju razni akteri, upravo zbog toga je vrlo bitna njihova umreženost i međusobna suradnja kada je u pitanju njegova provedba. Tu nema prostora za razilaženja tih aktera jer može doći do rascjepkanosti cijelog smisla i cilja tog procesa, što najviše šteti najvažnijim sudionicima procesa, a to su pojedinci zbog kojih je sve i pokrenuto.

\subsection{Oblici deinstitucionalizacije u klinikama}

Iskustva s procesom deinstitucionalizacije su raznolika te su se svi sudionici imali prilike upoznati s nekim njegovim oblikom, kao što to pokazuje primjer Osijeka, gdje su korisnici raseljeni u stambene jedinice, zatim Integrativni centar mentalnog zdravlja u Karlovcu i već spomenute udruge koje se bave programima izvanbolničke pomoći.

Nadalje, Sudionik 3 opisuje svoje iskustvo s ustanovama kao što su Bidružica i Mirkovec u Hrvatskom zagorju, gdje su boravile osobe lišene poslovnih sposobnosti koje su se zatim nastanile u kuće ili stanove gdje su imale određena zaduženja. Cilj je bio pojedincima vratiti samopouzdanje i ponovno ih uključiti u zajednicu. Taj je način jedna od najboljih opcija jer su tako pojedinci i dalje prisutni u poznatoj okolini te vode aktivan život. Oblici procesa deinstitucionalizacije stoga su dnevne bolnice i razne osnovane udruge i zajednice za osobe s duševnim poteškoćama, što navodi i jedan od sudionika: »Pa... što se tiče baš bolnice to je... ovisno od odjela do odjela, ali to je osnivanje dnevnih bolnica i nekih izvanbolničkih programa i Centar za rehabilitaciju u zajednici, to je već osnovano sad deset godina i to i možda čak i više je dovelo do toga da ti ljudi zapravo rijetko koriste bolničke usluge« (Sudionik 1).

U tom kontekstu potrebno je naglasiti da je, osim međusobne suradnje navedenih sudionika, potrebna suradnja samog pacijenta, koji mora biti upoznat s cijelim procesom. Dakle, naglasak je na tome da pacijent postaje partner u svojem izlječenju. On više nije pasivna osoba koja slijedi samo upute liječnika, nego aktivni sudionik procesa koji svojim iskustvom doprinosi vlastitomu izlječenju/ poboljšanju, ali i izlječenju/poboljšanju drugih pojedinaca. Time se treba opet dotaknuti pojma humanosti jer prema sudioniku »mogu biti najmoderniji trendovi, ako nema humanosti, nema ništa (Sudionik 2).

S time što pacijent postaje partner u svojem liječenju, može se povezati i uloga stručnjaka po iskustvu. Upravo iskustvo takvih osoba može uvelike doprinijeti liječenju neke druge osobe (Peer Work Hub, 2017). Iskustvo koje određena osoba ima proživljeno je „na vlastitoj koži“ te se stručnjak po iskustvu i osoba kojoj treba pomoć mogu na neki način poistovjetiti, čime, naravno, može doći do poboljšanja. 


\subsection{Faktori koji utječu na proces deinstitucionalizacije}

Kao što se već moglo zaključiti do sada, vrlo velik utjecaj na proces deinstitucionalizacije, osim svih drugih faktora, imaju financijska sredstva kojima određena klinika raspolaže. Glavnu ulogu u alokaciji financijskih sredstava ima država. ${ }^{1}$ Klinike posluju prema donošenim zakonima i mjerama, od strane države, prema mišljenju sudionika:

Država može pomoći funkcioniranju svih segmenata u društvu pa tako i zdravstvene skrbi općenito, a kroz to i skrbi za psihijatrijske bolesnike kroz izdvajanja koja se daju za zdravstvo. I, naravno, da su u našoj državi ta sredstva limitirana zbog toga što i situacija u državi nije, što se tiče privrede, baš najbolja i automatski, čim je takva situacija, čim je velik broj nezaposlenih ljudi, država može za zdravstvo, pa i za psihijatrijske bolesnike, izdvajati manje (Sudionik 3).

Dakle, klinike funkcioniraju prvenstveno tako što ovise o državi i njezinu načinu funkcioniranja u području zdravstvene skrbi. Iako klinike uvelike ovise o državi, ipak se u njih ulaže, posebno u neka područja, poput farmakologije, za koju su sudionici spomenuli da je u razini sa svjetskom, ako ne i bolja. Također, na stranicama Hrvatskog zavoda za zapošljavanje mogu se pronaći mjere aktivne politike zapošljavanja Od mjere do karijere, kao podrška transformaciji, deinstitucionalizaciji i socijalnoj uključenosti (HZZ, 2017). No postoji i druga strana ovog procesa. Neki smatraju da je Ministarstvo ulaganjem u taj proces »ugrabilo dobru priliku« (Derifaj, 2013) - ili zaista kako bi pružili jednak život svima u zajednici ili zbog skupljanja političkih bodova. Što se tiče politike, Sudionik 1 smatra da za početak treba postojati vizija što ljudima treba te da se trebaju provoditi one politike koje su korisne za zdravlje ljudi. Prema tome, trebaju se donositi zakonski propisi koji bi omogućili lakši rad s pacijentima, ali koji bi ujedno zaštitili njihova prava. Unatoč svim pozitivnim djelovanjima u kontekstu procesa, potrebno je, s druge strane, pripaziti i na to u koja se područja investira. Odnosno, jesu li to područja koja su samo u interesu investitora ili se zaista gleda samo na dobro osoba s duševnim smetnjama. Zbog toga je, između ostalog, potrebna edukacija, ali i reguliranje i redovito praćenje poslovanja.

Faktor koji također u velikoj mjeri utječe na proces je edukacija. Sudionici imaju jednako mišljenje po pitanju edukacije te smatraju da je ona potrebna kako bi se uopće znalo pristupiti osobama s duševnim smetnjama, kao što i govori jedan od njih: »Prvenstveno, trebamo se educirati. Dakle, stručnjaci koji će raditi u tom području, ali isto tako i društvo. Dakle, zaposliti osobu s težom duševnom smetnjom, za to biti stimuliran, kao poslodavac... ali imati i uvid, možda u neke limite te osobe. Ali isto tako u neke prednosti te osobe. Dakle, naprosto destigmatizirati« (Sudionik 4).

Goffman (2009) objašnjava kako se stigma odnosi na fizički oštećene ljude. No u tom kontekstu stigma je sram zbog boravka u psihijatrijskoj klinici te nemo-

1 Vrlo detaljan prikaz financiranja klinika u Hrvatskoj (po raznim kategorijama) može se pronaći na stranicama Ministarstva financija (državni proračun). Izvor: http://www.mfin.hr/hr/drzavniproracun-arhiva, 2017. 
gućnost funkcioniranja u vanjskom svijetu nakon izlaska iz klinike za psihijatriju. Nadalje, stigma također čini značajnu prepreku cjelovitomu oporavku i resocijalizaciji psihijatrijskog bolesnika te ona nije samo psihijatrijski i medicinski problem, nego odraz zrelosti, tolerancije i humanosti cijele zajednice (Čatipović i Čatipović, 2007, 71). Upravo zato tu veliku ulogu ima zajednica, odnosno obitelj, njima bliske osobe, ali i institucije koje im trebaju pomoći, primjerice, u pronalaženju posla. Jedan od sudionika govori kako je javnost uvijek više usmjerena na neka tjelesna stanja osoba nego na psihička:

Mnogo više se govori, što je ok, ali govori se o drugim kroničnim bolestima tipa karcinom dojke, dijabetes, karcinom prostate, što je izvanredno. I u psihijatriji ovog dijela koji je vezan za ovisnosti, alkoholizam, ali još uvijek je puno puno premalo preventivnih akcija za druge duševne smetnje i dizanje svijesti da osoba s duševnom smetnjom, tipa shizofrenije, nije stigmatizirana osoba, nije invalidna osoba, da se ni obitelj ni društvo nje nikako ne smije sramiti i gurati ju u zapećak, skrivati njezinu bolest. Jer tako dajemo poruku pacijentu „ti nisi bitan“, a to je prestrašno (Sudionik 4).

Jedan od primjera educiranja javnosti osnivanje je Dana prava osoba s duševnim smetnjama, koji se obilježava 6. lipnja. Kao što je već ranije spomenuto, djelovanje i utjecaj raznih udruga vrlo su bitni za proces deinstitucionalizacije. Između ostalog, udruge najviše djeluju u smjeru uključivanja osoba s duševnim poteškoćama u zajednicu tako što organiziraju razne programe, sastanke i edukacije. Pripadnici NVO sektora također uvelike doprinose razvoju tog procesa sudjelovanjem u navedenom kao peer worker (osoba s iskustvom). Upravo je zbog toga potrebno poticati njihov razvoj, kao što smatra i sudionik: »Razvoj udruga može potaknuti društvo, a osobito struka kroz edukaciju stanovništva od najmlađih do najstarijih « (Sudionik 7).

Osim stalne edukacije, jedan od sudionika smatra da je potrebno konstantno „slati impulse“:

Kako osvijestiti zajednicu, konstantnim, da tako kažem, slanjem impulsa, u smislu nekakvih stalnih sustavnih edukacija, javnih istupa, korištenjem svih mogućih oblika javnih nastupa, rada s ljudima, kontakta s ljudima koji boluju od duševnih bolesti. Znači, najjači destigmatizator je kontakt. To je ono što možemo, mislim, neke letke, neke brošure, sve je to super, ali kontakt s ljudima koji boluju od nekih psihičkih smetnji najjači je destigmatizator tako da u svakom slučaju puno javnozdravstvenih kampanja, puno medijskih natpisa, puno promocije desenzibilizirat ce te procese (Sudionik 5).

\section{Zaključak}

U hrvatskim klinikama za psihijatriju radi se na provođenju procesa deinstitucionalizacije na različitim razinama. Neki od sudionika taj pojam definiraju kao case management te objašnjavaju da je to odnos pacijenta i liječnika gdje pacijent više nije pasivna osoba, nego postaje partner liječniku i aktivno sudjeluje u svojem izlječenju/poboljšanju. Također, sudionici ističu i to da proces deinstitucionalizacije nije nužno zatvaranje institucija, nego smanjenje njihove upotrebe ili 
upotreba klinika za psihijatriju na drugačiji način. Obrasci procesa deinstitucionalizacije očituju se kao otvaranje dnevnih bolnica, provođenje inkluzije u smislu uključivanja psihičkih bolesnika u zajednicu na način da im zajednica pomaže, od obitelji do raznih drugih faktora, kao što su zavodi za zapošljavanje, razne vrste stručnjaka, poput psihijatara, socijalnih radnika, socijalnih pedagoga, psihologa, sociologa, terapeuta, zatim udruge itd. Potrebna je i svijest te edukacija zajednice kako bi došlo do destigmatizacije. To zahtijeva razumijevanje, adekvatnu skrb i brigu te pružanje prilika za zapošljavanje i aktivno sudjelovanje u zajednici. Prema tome, sudionici naglašavaju kako je važno da prvenstveno dođe do destigmatizacije. Veliku ulogu u procesu deinstitucionalizacije ima država, koja pruža materijalna sredstva klinikama, o čemu one ovise, te prema tome mogu dalje djelovati u tom smjeru. Prema mišljenju sudionika, proces ima uglavnom prednosti, a nedostatci se uglavnom odnose na financijske mogućnosti (i nedostatak edukacije). U skladu s time, neki proces smatraju nusproizvodom neoliberalne ekonomije. Iz toga proizlazi da je (prvenstveno) nastao zato što država ulaže manje sredstava u sektor zdravstva. S druge strane, veći naglasak stavlja se na humanost pa u hrvatskim klinikama za psihijatriju dolazi do sve veće humanizacije, a to se odnosi na tretman bolesnika i na odnos stručnjaka prema korisnicima. Također, dolaskom novih i modernijih načina liječenja došlo je do promjena u metodama liječenja koje su humanije. No nije sve crno-bijelo, što znači da proces ovisi i o vrsti duševne bolesti, odnosno o samoj toj osobi, čime se opet dolazi do toga da pojedine osobe jednostavno moraju biti smještene u klinike za psihijatriju. Ono što ograničava proces deinstitucionalizacije materijalna su sredstva koja ovise o državi. Sudionici predviđaju da ce se proces deinstitucionalizacije nastaviti razvijati jer će psihijatrija s vremenom postati još modernija. Prateći svjetske trendove, kao i do sada, i hrvatska psihijatrija mogla bi taj proces dostići u puno većem zamahu te bi se kroz nekoliko godina to vjerojatno očitovalo u još većem broju otvorenih dnevnih bolnica, osnivanju udruga za inkluziju i slično, što znači da bi bilo manje hospitaliziranih pacijenata.

\section{Literatura:}

Bachrach, Leona L. (1976). Deinstitutionalization: An Analytical Review and Sociological Perspective. Washington DC: U. S. Goverment Printing Office. URL: https://archive. org/stream/deinstitutionali00bach\#page/n1/mode/2up (19.11.2016.)

Berger, Peter L.; Luckmann, Thomas (1992). Socijalna konstrukcija zbilje. Zagreb: Naprijed.

Bruce, Steve; Yearley, Steven (2006). U: The Sage Dictionary of Sociology. London: SAGE Publications Ltd. URL: https://rfdvcatedra.files.wordpress.com/2014/08/sagedictionary.pdf. (18.07.2017.)

Čatipović, Marija; Čatipović, Vinko (2007). Stavovi učenika prema psihičkim bolesnicima. Medicinski vjesnik, 39(1-4), 71-76.

Derifaj, Danka (2013). Druga strana projekta deinstitucionalizacije domova za osobe s posebnim potrebama. Provjereno.dnevnik.hr. URL: https://provjereno.dnevnik.hr/ clanak/druga-strana-projekta-deinstitucionalizacije-domova-za-osobe-s-posebnim-potrebama—311353.html (20.08.2017.) 
Encyclopedia of Mental Disordres (2017). URL: http://www.minddisorders.com/Br-Del/ Deinstitutionalization.html (16.12.2017.)

Foucault, Michael (1994). Nadzor i kazna: Rađanje zatvora. Zagreb: Informator.

Goffman, Erving (2011). Azili: Eseji o društvenom položaju pacijenata bolnica za mentalno obolele i drugih utočenika. Novi Sad: Medi Terran publishing.

Grozdanić, Velinka; Rittossa, Dalida (2017). Prava osoba s duševnim smetnjama u psihijatrijskim ustanovama u Republici Hrvatskoj - empirijska analiza. Zbornik Pravnog fakulteta Sveučilišta u Rijeci, 38(3), 947-981.

Jakovljević, Miro; Begić, Dražen (2013). Socijalna psihijatrija danas: Izazovi i mogućnosti. Socijalna psihijatrija, 41(1), 16-20.

Jukić, Vlado (2017). Proglas povodom Dana prava osoba s duševnim smetnjama. U: Hrvatsko psihijatrijsko društvo. URL: http://www.psihijatrija.hr/site/?p=3017 (11.08.2017.)

Miljenović, Ana (2013). Ekonomska kriza — pokretač transformacije profesije socijalnog rada? Ljetopis socijalnog rada, 20(1), 51-70.

Od mjere do karijere: Mjere aktivne politike zapošljavanja. URL: http://mjere.hr/ (20.08.2017.)

Open Society Foundations (2015). What Is Deinstitutionalization? URL: https://www. opensocietyfoundations.org/explainers/what-deinstitutionalization (08.08.2017.)

Oxford dictionary. URL: https://en.oxforddictionaries.com/definition/deinstitutionalize (8.1.2018.)

Peer Work Hub (2017). What is peer work? URL: http://peerworkhub.com.au/what-ispeer-work/ (19.12.2017.)

Pow, Joni Maria Lee (2012). The occurrence and effectiveness of deinstitutionalization of the mentally ill in the pre-antipsychotic era (Magistarski rad). Louisiana State University and Agricultural and Mechanical College. URL: https://digitalcommons.lsu. edu/cgi/viewcontent.cgi?referer $=$ https://www.google.hr/\&httpsredir $=1 \&$ article $=39$ $97 \&$ context $=$ gradschool_theses $(16.12 .2017$. $)$

Rozman, Bojana (2007). Utjecaj u zajednici utemeljene rehabilitacije na kompetentnost deinstitucionaliziranih osoba s intelektualnim teškoćama. Hrvatska revija za rehabilitacijska istraživanja, 43(2), 67-81.

Shen, Gordon C.; Snowden, Lonnie R. (2014). Institutionalization of deinstitutionalization: A cross-national analysis of mental health system reform. International Journal of Mental Health Systems. URL: https://ijmhs.biomedcentral.com/articles/10.1186/1752-4458-8-47 (21.03.2018.)

Štrkalj Ivezić Slađana; Jukić, Vlado; Hotujac, Ljubomir; Kušan Jukić, Marija; Tikvica Ana (2010). Organizacija zaštite mentalnog zdravlja u zajednici. Liječničcki vjesnik, 132, $1-2,38-42$.

Štrkalj Ivezić, Slađana; Mužinić, Lana; Filipac, Vanda (2010). Case management - a pillar of community psychiatry. Psychiatria Danubina, 22(1), 28-33.

Zakon o zaštiti osoba s duševnim smetnjama, (1998). URL: http://bolnica-vrapce.hr/web/ wp-content/uploads/2013/11/ZAKON-O-ZASTITI-OSOBA-S-DUSEVNIMSMETNJAMA1.pdf (19.08.2017.) 


\title{
The Deinstitutionalization Process of Psychiatric Clinics in Croatia
}

\author{
Maja Odorjan*, Ivan Balabanić**, Tina Štefan***
}

\section{Summary}

This paper presents studies on the deinstitutionalization process of psychiatric clinics in Croatia, namely, the beginning of the process, its various forms and its indicators. The aim of the paper is to define patterns of the deinstitutionalization process of "total institutions", for example, of psychiatric clinics in Croatia. The designated aims of the research encompass the main causes and indicators of the process, expert opinions as also the opinions of employees of non-government organizations (NGO). Interview methodology was applied and involved 11 participants. Research has pointed out that a deinstitutionalization process does indeed exist in psychiatric clinics in Croatia, and that it is dependent on state funding. The process occurs in the form of daycare hospitals, support and various other therapies which incorporate users of psychiatric clinics into the community. Success of the process, as well as its further development, is determined by the involvement and cooperation of employment bureaus, educational institutions and the entire community.

Key words: institutions, "total institutions", deinstitutionalization process, psychiatric clinics

* Maja Odorjan, Master of Sociology, MSA Adria d.o.o. Address: Petrinjska 42a, 10000 Zagreb, Croatia. E-mail: maja.odorjan@gmail.com

** Ivan Balabanić, PhD, Assistant Professor, Catholic University of Croatia. Address: Ilica 242, 10000 Zagreb, Croatia. E-mail: ivan.balabanic@unicath.hr

*** Tina Štefan, Master of Sociology, Society of Physically Disabled Persons of Međimurje County. Address: Dr. A Starčevića 1, 40000 Čakovec, Croatia. E-mail: tina.stefan05@gmail.com 